\title{
REPRESENTATION OF THE INDONESIAN PRESIDENT CANDIDATE LEADERSHIP AT CNNINDONESIA.COM
}

\author{
Yulia Sofiani Zaimar', Ajeng Dinar Wisesa Wardhani ${ }^{2}$ \\ Program Studi Pendidikan Bahasa Inggris, \\ Fakultas Bahasa dan Seni, Universitas Indraprasta PGRI \\ I'oleel27@yahoo.com, ${ }^{2}$ ajengdinar13@gmail.com
}

\begin{abstract}
Abstrak
Dalam penelitian ini, peneliti meneliti peran media dalam membentuk opini publik tentang peristiwa, dalam kerangka media, yang menyebarkan informasi penentu informasi produk yang dihasilkan dari media. Peneliti ingin memeriksa dan mengatasi sikap dan gagasan yang disampaikan oleh bentuk nonverbal di media. Kepemimpinan politik adalah wacana, yang harus selalu dimasukkan dalam semua diskusi politik selama pemilihan presiden, termasuk dalam pemilihan presiden 2019 mendatang di Indonesia. Pada kenyataannya, kriteria kepemimpinan politik yang demokratis tidak hanya ditetapkan, itu adalah kriteria kepemimpinan politik yang khas yang kadang-kadang bertentangan dengan prinsip-prinsip demokrasi. Dalam konteks Indonesia. Dalam penelitian ini, teori Foucault tentang Analisis Wacana Kritis (CDA) terkait dengan apa yang terjadi di masyarakat, seperti dijelaskan Harbermas Jurgen.
\end{abstract}

Kata Kunci: media, opini, wacana, politik, pemilu

\begin{abstract}
In this research, the researchers examine the importance of the role of the media in shaping public opinion about an event, the framework of a media in the dissemination of information determines the information products produced from the media. The researchers would like to examine and to investigate the attitudes and ideas conveyed by non-verbal forms, contained in media. Political leadership constitutes a discourse, that must always be included in all political discussions, during the presidential election, including in the upcoming 2019 presidential election in Indonesia. In reality, the democratic political leadership criteria are not simply established, especially in the face of two things: the first is the existence of local values in which each country has the criterion of distinctive political leadership that sometimes contradicts the principles of democracy. In the Indonesian context. In this research, the researchers intended to use the theory used, namely the theory behind the Critical Discourse Analysis (CDA) method, comes from Foucault, relating to what happens in society, in what Harbermas Jurgen had explained.
\end{abstract}

Keywords: media, opinion, discourse, politic, election

\section{INTRODUCTION}

Nowadays, the information, which is becoming to be the favorite in almost all types of media in Indonesia, is political information. Understandably, Indonesia has a big party, namely the presidential and vicepresidential elections for the period 2019-2024, namely the battle between two presidential and vice presidential candidates. The first candidate is Joko Widodo with Ma'ruf Amin, and the second is Prabowo Subiyanto and Sandiaga Uno. The decision of the Constitutional Court to decide on the 2019 presidential election lasted a lap. Therefore, the two candidates would focus for the presidential election this 
time, desperately trying to win. They would mobilize all means, including using medias. The things that will be discussed in this research, taken from the text cnnindonesia.com, which is produced by democratic actors. cnnindonesia.com is managed by PT Trans News Corpora, a regional group of PT. Trans Media Corpora. Based in Jakarta, this news site features national, regional, international, sports, business and economic news, as well as celebrities and lifestyles. cnnindonesia.com also manages online forums and communities via Facebook, Twitter and also Google.

In this research, the researchers would examine the importance of the role of the media in shaping public opinion about an event, the framework of a media in the dissemination of information determines the information products produced from the media. So that each media has its own ideological strategy to express its intentions. The ideology here can be interpreted as interests (Mandarani, 2013). As the interests of each media are different, the neutrality of the media becomes questionable, especially for the issues related to the 2019 presidential election. This presidential election of 2019 has made Indonesia a competitive space between the various discourses defended by the political elites through their respective spokespersons. Inevitably, at the 2014 political stage, speech competition was underway in Indonesia. A discourse (prior discourse) submits an affirmation of truth, while another discourse leads a criticism or an attack, and then the first speech is returned in the form of defense (Rahardjo, 2007).

All those things above are based on expressions of thought Alvesson in Rahardjo, which says that "language is a means in the discourse process."
(Rahardjo, 2007) By examining linguistic structures for a discourse conveyed by the media, the public can know ideological strategies such as what is used and penetrated by certain media. In relation to the linguistic structure, the examination of the discourse by means of internal structures or text micro-structures can constitute a first alternative to Understanding the interests of a media.

Political leadership constitutes a discourse, that must always be included in all political discussions, during the presidential election, including in the upcoming 2019 presidential election in Indonesia. This question is one of the dominant discourses that emerged in the process of political communication regarding the 2019 presidential election on cnnindonesia.com. Each presidential candidate has competed to show the best in political leadership in a variety of ways. In the countries Democratic, based on empirical studies conducted since the 1960s (Hacker, 2004). "The quality of political leadership uses certain criteria such as competence, strength, reliability, integrity, capacity, heat or proximity to people". These seven criteria are ideal for the democratic process when the object of rational discussion is centered. For example, political programs that become the vision and mission of the presidential candidate are not objects of cultural discussion. One of them is the identity of the candidate for the presidency, the candidate and the network.

In reality, the democratic political leadership criteria are not simply established, especially in the face of two things: the first is the existence of local values in which each country has the criterion of distinctive political leadership that sometimes contradicts the principles of democracy. 
In the Indonesian context, for example, various studies of leadership indicate that Indonesian political leaders are the ideal, namely the ethnic characters and has military training (Syamsuddin, 1993). Based on that quotation, it could be explained that the construction of the identity of Indonesian, Islamic, Javanese and military political leaders in Indonesia has been strongly naturalized in politics since the New Order and perhaps until now, but these criterias have unfortunately hidden the practice of power that has undermined the democratic process itself, including implicit Muslim leaders. and the Javanese leaders who have hidden the political practices identity.

Secondly, the emergence of the media in the process of political communication is one of the points where the process of forming the political leadership of a future leader takes place in a more complex way. If before there was a media management figure formed with direct communication, political communication was now mediated with a range of targets wider. But there is a problem. Behind the complex mediated political communication, there is a long process missing, namely a political leadership formed by a long and real fight. Meanwhile, the media allow the construction of political personalities instantly.

This article aims to explore the practice of power in the process of political communication regarding presidential political leaders 2019 on social networks, Cnnindonesia.com, which uses a political imaging mechanism. To elaborate, the researcher answers at least several research questions, which are problem statements. First, how are the political leaders of the two candidates represented on Cnnindonesia.com? The second question to ask is what is the practice of power hidden behind the text of the speech of the presidential political leadership. This study Beside discourse, the researchers would like also to use the definition of public space, that was developed by Fracer who developed Habermas' point of view. The public space from the point of view of the bourgeois public space that launches a lawsuit against the demands of the state public, which is formulated in the form of questions to determine whether the state served the public interest (Habermas, 1989).

\section{Theory}

In this research, the researchers intended to use the theory used, namely the theory behind the Critical Discourse Analysis (CDA) method. The CDA (Fairclough, 1992) argues that "text is a social practice and not just a tool to convey information". In a hidden ideology of text and hegemony. Using ideological theory, Fairclough refers to the point of view of Louis Althusser (Fairclough, 1992) who uses ideology to understand how it works in society. While using the theory of hegemony refers to views, Gramsci who interpreted hegemony as leadership or dominance in various fields such as economic, political, cultural and ideological domains of a society (Fairclough, 1992).

Based on CDA, according to Michel Foucault, the concept of power cannot be dissociated from knowledge as an integral part of the concept that functions within the structures of power. The power structure is spread everywhere and in various fields, such as politics, legal, social, religious, to the field of health. Knowledge-power works through discursive practices prevalent in people's lives. For example, speech on health or speech on the order. 
By studying the practice of discourse through language and knowledge - we will know how the power - or the power of a regime - acts against the peoples of which it is composed. Power is not only controlled by the state, but can be measured, and power is everywhere, because power is a dimension of relationships (Foucault, 2002). Foucault's distinctive character: He does not describe what power is, but how it works in certain fields.

The researchers attempt to relate the results of the practice of power in cnnindonesia.com, then confirmed the use of the theory of deliberative democracy (Habermas, 1996). Identification is mainly done by looking at the section, where democratic practices on cnnindonesia.com did not encourage the democratic process. If political news in a democratic cnnindonesia.com had to meet certain criteria that calls an ideal communication procedure (Habermas, 1996). In the book, the first thing that is explained is the protection of private space, namely the way in which public space protects private matters such as identity (gender, ethnicity, religion, etc.). The second thing is an argumentative discussion, namely the exchange of information using critical reasons and validity. The last thing to do is to involve all parties (included), all parties involved in a policy, which are under discussion.

Representation in this research refers to the definition of representation in the opinion of Fowler that influences Fairclough's thinking across Halliday. Fowler defines representation as the result of coding the human experience of the world using language. With reference to the definition of representation, in this study, representation is interpreted as a form of reappearance, symbolization and coding of the two candidates by means of news texts. In the meantime, the discursive analysis of the practice is an analysis of the processes of production, consumption, and distribution of the text, the extent of this process differing in each discourse in terms of social factors that surround it. In the sociocultural analysis, researchers cite what Fairclough said about attempts to identify hidden power practices in ideological theory and hegemony texts (Fairclough, 1992).

\section{RESEARCH METHOD}

This research is a qualitative research based on the main method of critical discourse analysis (CDA) developed by explained in the theoretical framework. In this study, researchers used Fairclough's CDA framework $(1992,91)$ "The first thing is text analysis, the second is the practice of speech, and the last is the sociocultural practice". The text analysis, which uses this method, focuses on identifying the representation of 2019 presidential candidates, built by the news on Cnnindonesia.com of Prabowo and Jokowi. The search data includes the text produced by Cnnindonesia.com, which reviews the "fighting between Prabowo and Jokowi", which was produced during the campaign period leading up to the 2019 presidential election.

Talking about qualitative, the descriptive method is a research method conducted solely from existing facts or phenomena that live empirically on speakers, so that the resultant perian language form as it is (Sudaryanto, 2002). Based on the above explanation, this study uses a qualitative descriptive method to describe the existing forms of conversational implicature and classify the conversational implicature forms 
contained in the film. This descriptive method is carried out through the collection of data which is compiled, analyzed, classified, interpreted or discussed and concluded.

\section{FINDINGS AND DISCUSSION}

In this context, the imaging policy is reflected in the practice of candidate representation, which is considered as the process of displaying an object in the text. Using the concept of practice of political imagology to describe the results of the text analysis also shows that research. The representation of the presidential candidate was therefore nothing more than a "political advertisement" which positioned the presidential candidate as a commodity sold to the public. According to Kellner, "The representation of reality in advertisements is often perceived as a representation that tends to distort what is called dissimulation or false consciousness", as the results of this study (Noviani, 2002).

Euphemism is known as a positive representation of selfpresentation. It is a strategy to describe the creator of the text as a positive tagged party (Van Dijk, 2004). This trend is part of interactional strategies and social cognition aimed at avoiding the negative impressions of the recipient of the text. Thus, the use of euphemization strategies is here aimed at "imposing" impressions on the other person or the recipient of the text. The opposite of euphemization is a derogation. Dijk (2004) argues that "The derogation strategy is known as the negative representation of others (negative representation). Derogation is a polarization strategy between "included in the group" and "that is not included". The creator of the text uses this strategy to describe the other part with a negative image". Through the analysis of derogation and euphemization can be known how text writers use discursive strategies to convince the recipients of the text. So, if this is a problem, of who is in the media, referring to the word "we", who is considered as "their" and this manifests in different forms of reporting even if the reality refers to the same thing.

In the text below, which was launched from cnnindonesia.com news portal, December 9th, Prabowo-Sandi Putting the Voice of the Central Java PDIP Shake Mission. It can be deduced that Prabowo does not use the method of positioning in the area in a raw way. However, it's like reducing regulations, Joko Widodo's defense base and PDIP will be slow. This can be seen from the sentence:

Pada Pemilu 2014 PDIP tercatat mendominasi perolehan suara di Jawa Tengah. PDIP berhasil mendominasi delapan dari 10 daerah pemilihan di Jawa Tengah kini Ferdinand menargetkan Prabowo-Sandi bisa setidaknya merebut $35-40$ persen suara di Jawa Tengah (CNN Indonesia, 2018c).

In this case, the researchers would link the text above to a quote from Alvesson, according to which discourse is a speech or a writing as an expression of thought (Rahardjo, 2007), then language is a tool in the discourse process. By examining the linguistic structure of a speech made by the media, we can determine which ideological strategies are used and penetrated by certain media. In relation to the linguistic structure, the examination of the discourse by means of internal structures or micro-text structures can constitute a first 
alternative to the understanding of the interests of a media. According to van Dijk, micro-structure refers to the local meaning of a discourse by searching for and analyzing words, sentences, propositions, and sentences (Rosidi, 2007). The use of words, sentences, sentences and phrases is considered by van Dijk as part of the strategies of the speakers or writers to achieve their goals. This strategy is seen not only as a means of conveying information, but also as a technique that allows the creator of the text to influence and control the minds of readers or listeners, to create support, to strengthen the legitimacy and power and to get rid of opponents or opponents (Eriyanto, 2009).

According to the quote from cnnindonesia.com, the author makes the connection with what Van Dijik said that Micro-structure refers to the local significance of a discourse by researching and analyzing words, phrases, propositions and expressions (Rosidi, 2007). The use of words, phrases, propositions and expressions is considered by van Dijk as part of the strategies of speakers or writers to achieve their goals. This strategy is seen not only as a means of transmitting information, but also as a technique of the creator of the text to influence and control the minds of readers or listeners, create support, strengthen legitimacy and power, and get rid of opponents or opponents (Eriyanto, 2009). Those things are provided in:

Sebelumnya, Prabowo sempat geram karena banyak media tak meliput Reuni 212, di Monumen Nasional (Monas), Minggu (2/12). Selain itu, Prabowo mengeluhkan soal pemberitaan tentang jumlah massa Reuni 212. Dia menganggap media sudah berpihak dan bahkan meminta pendukungnya tak usah menghormati wartawan (CNN Indonesia, 2018a).

Connecting to the quotation above, with this concept, researchers could prove the initial purpose of this research, which was to determine how the media, pro Joko Widodo and Ma'ruf Amin, are the presidential and vice presidential candidates, posing as political opponents to both candidates. that it supports, for example by emphasizing, sharpening, softening, glorifying, harassing, deviating or obscuring an event or an action creating a certain impression of an unsupported couple of candidates, PrabowoSandiaga, through the media discourse. From the quotation above, it would be told that the ideal presidential representation is built by building an image of political leadership that is considered good for the Indonesian people, on the contrary, the presidential candidate is not ideally constructed with an image of political leadership deemed bad for the Indonesian people. During this process, the imaging policy took place in the political news published by cnnindonesia.com.

Meanwhile, in regarding their identity, on using their image, Prabowo's presidential candidate does not seem to need any hard work to portray Prabowo as a member of the dominant Javanese Muslim group, because of two elements legitimizing the identity attached to them. This is shown by the supporting parties, the majority of which are Islam-inspiring parties, like PAN, PBB, PPP and PKS. In addition, the Indonesian public has long known Prabowo as a Javanese and Muslim family, stemming from the past of his father and father-in-law, namely President Soeharto, second president of the Republic of Indonesia. This 
description of the image using identity ultimately implies giving birth to two contradictory ideologies in Indonesia, namely between Muslims and nonMuslims. This can be seen from the sentence:

Awalnya beberapa kelompok
massa aksi menyanyikan lagu
Indonesia Raya. Koordinator
aksi kemudian memekikkan
takbir yang diikuti oleh massa
yang hadir. Ia lalu menyerukan
nama Prabowo. "Prabowo!" seru
koordinator aksi. "Presiden!"
jawab massa dengan suara
lantang (CNN Indonesia,
2018b).

The context of the news above, shows that the existence of a dominant ideology is implicit in the use of this ideology to build the ideal candidate, namely the javano-Muslim. In this case, the local values of leadership in Indonesia's political history were again evoked by both parties as an ideal imaging tool for political leadership.

On the other hand, in the context of the 2019 presidential election, the Indonesian's nationalism was exploited as a tool of ideal presidential legitimacy, but only used the figure of Soekarno as its creator. Although both exploit the figure of Soekarno, but use different models. Jokowi focused more on the use of Sukarno's ideas, while Prabowo focused more on the use of Soekarno's physical symbols such as caps, two-garment clothes and speech. The above explanation shows how a representation is shaped to construct the ideal figure of presidential leadership from the use of characters such as: simple-glamor, civilian-military; formation of Muslim-Non-Muslim, and nationalism.

Meanwhile, in relating to the existence of reality-formulating activities, it can be said that the two presidential candidates are a binary opposition. The binary opposition is consistent with Foucault's opinion on the relationship between discourse, power and knowledge (Hall, 1997). In his book, Foucault shows the relation between the discourse of science and power. The discourse on science that seeks to find the right and the wrong is essentially motivated by the will to rule. Science is done to determine what is right and eliminate what is perceived as false.

In this case, the discursive activities cannot be separated from the desire to govern, and conversely, the formation of knowledge is always surrounded by power. In the context of binary opposition, in this case, it becomes clear that the will to truth is an expression of the will to govern. It is impossible for knowledge to be neutral and pure. Here, there is always a correlation, namely that knowledge contains power as well as knowledge contains power A scientific explanation tries to master by eliminating other explanations of science. In addition, the knowledge gained through technology is easy to use to impose something on society. Because even in the era of high technology, there are still practices, so we cannot talk about the progress of civilization. From the research, hopefully, could see, what has been happening, is only a change the instruments, which is used to gain power.

\section{CONCLUSION}

The explanation above explains the poor quality of the discussions in the political communication process on the 2019 presidential political speech, mainly because of deliberative democratic procedure violations, namely a rational dialogue. A rational 
dialogue, which should be conducted in an equal, equal, interactive and participatory way, is not going well because of the practice of ideological power hidden behind the text. The distortion of communication results from the formation of a binary opposition and the use of propaganda techniques that position the actors of democracy unequally.

Based on the results of the research, it can be concluded that the process of political communication on Twitter has found major challenges, which stemmed from the existence of political imagery who manipulates the messages (messages) of political communication. From the perspective of the critical analysis of the speech, the production of messages is inseparable from the character of the virtual public as recipient of the message.

This means, that the image politics, reported in Cnnindonesia.com, also reflects the face of the press, which has a pattern of image-controlled consumption (image). The ideal candidate for the presidency does not have to be determined by his competence as a leader, but rather by the signs or symbols attached to Muslim-Non-Muslim, Non-Indigenous). The symbolic value then becomes a commodity that determines the political constituency choice. The media has the ability to influence public opinion and behavior. The media play a very important role in transmitting and stimulating political issues in every political campaign. The media have their own tendency to convey the speech to the public, it can be said, the election of 2019 seems to be a place of speech war between the media. In relation to the purpose of this study, we can conclude how Jokowi and Prabowo are represented by the conclusion that the derogation and euphemization strategy is used in discursive practice.

\section{REFERENCE}

CNN Indonesia. (2018a). Amarah Prabowo pada Pers Dinilai Bisa Jadi Bumerang. Retrieved December 10, 2018, from https://www.cnnindonesia.com/ nasional/20181207063557-32351761/amarah-prabowo-padapers-dinilai-bisa-jadi-bumerang

CNN Indonesia. (2018b). Massa Reuni Aksi 212 Serukan Prabowo Subianto Presiden 2019. Retrieved December 10, 2018, from

https://www.cnnindonesia.com/ nasional/20181202075345-20350455/massa-reuni-aksi-212serukan-prabowo-subiantopresiden-2019

CNN Indonesia. (2018c). prabowo sandi pasang misi goyang suara pdip di jawa tengah. Retrieved from

https://www.cnnindonesia.com/ nasional/20181209164243-32352253/prabowo-sandi-pasangmisi-goyang-suara-pdip-dijawa-tengah)

Eriyanto. (2009). Analisis Wacana (pengantar analisis teks media). Yogyakarta: LKis. https://doi.org/10.4271/2011-010343

Fairclough, N. (1992). Discourse and Social Change. Cambridge: Polity Press.

Foucault, M. (2002). The Order of Things: Archeology of the Human Sciences. New York: Vintage Books. 
Habermas, J. (1989). The Structural Transformation of Public Sphere: An In-quiry into Category of Bourgeois Society ,Thomas Burger (terj.). Cambridge: Polity Press.

Habermas, J. (1996). Between Facts and Norms: Contributions to a Discourse Theory of Law and Democracy. Cambridge: Polity Press.

Hacker, K. L. (2004). Introduction: The continued importance of candidate image construct. In K. L. Hacker (Ed.), Presidential candidate images. oxford: Rowman \& Littlefield.

Hall, S. (1997). Representation: Cultural Represetation and Cultural Practices. London: Sage Publication.

Mandarani, V. (2013). Pencitraan Joko Widodo dan Fauzi Bowo dalam Media Harian Kompas Pada Pilkada DKI Jakarta 2012. Universitas Airlangga.
Noviani, R. (2002). Jalan Tengah Memahami Iklan. Yogyakarta: Pustaka Pelajar.

Rahardjo, M. (2007). Hemeneutika Gadamerian: Kuasa Bahasa dalam Wacana Politik Gus Dur. Malang: UIN-Malang Press.

Rosidi, S. (2007). Analisis Wacana Kritis sebagai Ragam Paradigma Kajian Wacana (Critical Discourse Analysis as Variance of Paradigm of Inquiry on Discourse). Malang: UINMalang Press.

Sudaryanto. (2002). Metode Linguistik Ke Arah Memahami Metode Linguistik. Jakarta: Balai Pustaka.

Syamsuddin, M. D. (1993). Political Stability and Leadership Succession in Indonesia. Contemporary Southeast Asia, 15, No. 1, 12-23. Retrieved from https://www.jstor.org/stable/257 98181

Van Dijk, T. A. (2004). Ideology and Discourse: A Multidisciplinary Introduction. Barcelona: Pompeu Fabra University 